\title{
AN ANALYTICAL STUDY OF ANATOMICAL VARIATIONS IN CLINICAL RHINOSINUSITIS
}

\author{
P. B. Kameswara Rao ${ }^{1}$, S. Ramesh ${ }^{2}$
}

${ }_{1}^{1}$ Associate Professor, Department of ENT, GEMS, Ragolu, Srikakulam, Andhra Pradesh, India.

${ }^{2}$ Assistant Professor, Department of ENT, RIMS, Srikakulam, Andhra Pradesh, India.

ABSTRACT

\section{BACKGROUND}

The term 'rhinosinusitis' is defined as inflammation of the mucosa of the nose and paranasal sinuses. Anatomical variations are predisposing factors for causing rhinosinusitis. A precise knowledge of the anatomy of the paranasal sinuses is essential for the clinician. With the advent of Functional Endoscopic Sinus Surgery (FESS) and Coronal Computed Tomography (CT) imaging, considerable attention has been directed toward paranasal region anatomy. Remarkable anatomic variations of nasal septum and lateral of nose region and their possible pathologic consequences should be well defined in order to improve success of management strategies and to avoid potential complications of endoscopic sinus surgery.

The objective of this study is to determine the anatomical variations leading to clinical sinusitis and to compare them with normal population.

The aim of this study is to analyse the relationship of anatomical variations and rhinosinusitis.

\section{MATERIALS AND METHODS}

It is a descriptive study. Patients admitted in our hospital from $1 / 1 / 2016-31 / 7 / 2017$ with symptoms of sinusitis were randomly selected and considered for CT paranasal sinuses for detection of any anatomical variations.

Design- This is a case control study. A prospective study of 200 patients was done on the CT scans of patients with clinical sinusitis.

\section{RESULTS}

Anatomical variations leading to sinusitis were Concha Bullosa (43\%), Deviated Nasal Septum (34.6\%), Agger Nasi (41.12\%), Haller Cell (10.28\%), Paradoxical Middle Turbinate (10.28\%), Large Bulla (7.48\%), Onodi Cell (5.61\%) and Pneumatised Uncinate $(2.8 \%)$.

\section{CONCLUSION}

It was concluded that the anatomical variations play a significant role in rhinosinusitis and prior CT PNS is essential for diagnosis and treatment.

\section{KEY WORDS}

Rhinosinusitis; Computed Tomography; Concha Bullosa; Osteomeatal Complex.

HOW TO CITE THIS ARTICLE: Rao PBK, Ramesh S. An analytical study of anatomical variations in clinical rhinosinusitis. J. Evolution Med. Dent. Sci. 2018;7(35):3863-3867, DOI: 10.14260/jemds/2018/865

\section{BACKGROUND}

The term 'rhinosinusitis' is defined as inflammation of the mucosa of the nose and paranasal sinuses. Anatomical variations are predisposing factors for causing rhinosinusitis.

A precise knowledge of the anatomy of the paranasal sinuses is essential for the clinician. With the advent of Functional Endoscopic Sinus Surgery (FESS) and Coronal Computed Tomography (CT) imaging, considerable attention has been directed toward paranasal region anatomy. Remarkable anatomic variations of nasal septum and lateral of nose region and their possible pathologic consequences should be well defined in order to improve success of management strategies and to avoid potential complications of endoscopic sinus surgery.

Currently, CT scanning is the standard imaging in the evaluation of the paranasal sinuses. This, combined with endoscopy, gives an applied anatomical view of the region and of the anatomical variants that are often found.

'Financial or Other Competing Interest': None.

Submission 03-08-2018, Peer Review 15-08-2018,

Acceptance 18-08-2018, Published 27-08-2018.

Corresponding Author:

Dr. S. Ramesh,

Assistant Professor,

RIMS, Srikakulam-532001, Andhra Pradesh, India.

E-mail: rameshseepana@rediffmail.com

DOI: $10.14260 /$ jemds $/ 2018 / 865$

\section{Aim of the Study}

To analyse the relationship of anatomical variations and rhinosinusitis.

\section{MATERIALS AND METHODS}

The present study is a descriptive study of anatomical variations in clinical rhinosinusitis, was carried out in the Department of ENT, Great Eastern Medical School and Hospital, Ragolu, Srikakulam.

Patients admitted in our hospital from 1/1/2016 $31 / 7 / 2017$ with symptoms of sinusitis were randomly selected for the study.

$\begin{array}{ll}\begin{array}{l}\text { Rhinosinusitis- Symptoms/ Signs } \\ \text { Major }\end{array} & \text { Minor } \\ \text { Facial pain/pressure } & \text { Headache } \\ \text { Facial congestion/fullness } & \text { Fever (Non-acute) } \\ \text { Nasal obstruction/blockage } & \text { Halitosis } \\ \text { Nasal discharge/purulence/ } & \\ \text { discoloured } & \text { Fatigue } \\ \text { Hyposmia/anosmia } & \text { Dental pain } \\ \text { Purulence on nasal examination } & \text { Cough }\end{array}$

Fever (Acute RS only) Ear pain/pressure/fullness Requires 2 major factors or 1 major and 2 minor factors. 


\section{Inclusion Criteria}

1. Patients with symptoms and signs of rhinosinusitis between 15 and 60 years.

2. Nasal endoscopy, suggestive of rhinosinusitis.

3. CT-PNS, suggestive of rhinosinusitis.

\section{Exclusion Criteria}

1. Patients with adenoid hypertrophy, sinonasal polyposis and allergic fungal sinusitis.

2. Complicated rhinosinusitis, sinonasal malignancy.

3. Previous sinonasal surgery.

Clinical material for the present study comprises of 200 cases of rhinosinusitis. The patients were examined clinically and further investigated using DNE and CT-PNS. Thickness of slice was $1 \mathrm{~mm}$ CT scan done for both bony and soft tissue windows. The presence of anatomical variations and mucosal changes has been found out in CT scan PNS. The presence of anatomical variations was also documented along with radiological features of chronic rhinosinusitis.

\section{Ethical Considerations}

The study got clearance by the Institutional Ethical Committee before its commencement. Also, a written informed consent was taken from all the patients before participating in the study.

\section{RESULTS}

\section{Age Distribution}

Of the 200, 60 patients (30\%) belong to age group $21-30$ years, $56(28 \%)$ belong to age group 15 - 20 years, 52 (26\%) belonged to 31 - 40 years category, $26(13 \%)$ were in $41-50$ years category, only $6(3 \%)$ in 51 - 60 years and no cases below 10 years.

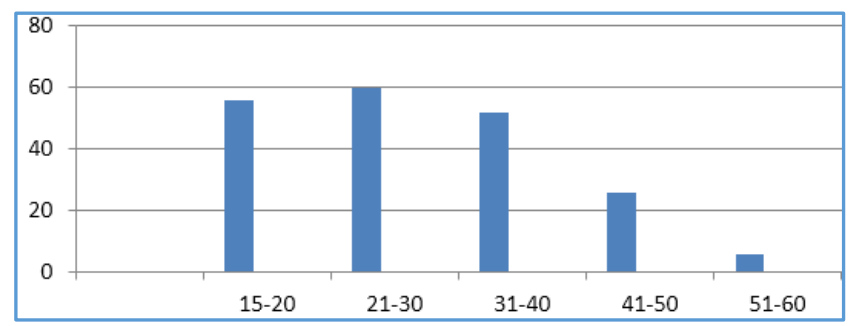

\begin{tabular}{|c|c|c|c|}
\hline Sl. No. & Category (Years) & No. of Cases & $\mathbf{\%}$ \\
\hline 1 & $15-20$ & 56 & 28 \\
\hline 2 & $21-30$ & 60 & 30 \\
\hline 3 & $31-40$ & 52 & 26 \\
\hline 4 & $41-50$ & 26 & 13 \\
\hline 5 & $51-60$ & 6 & 3 \\
\hline Total & $\mathbf{2 0 0}$ & $\mathbf{1 0 0}$ \\
\hline
\end{tabular}

\section{Sex Distribution}

Of the 200 cases, 106 (53\%) were males and 94 (47\%) were females.

\section{SEX DISTRIBUTION}

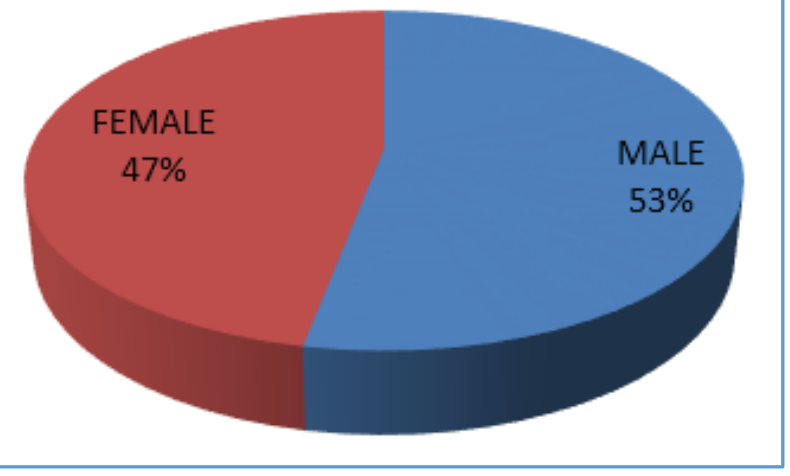

Incidence of Symptoms in Rhinosinusitis

Major presenting symptoms were Nasal obstruction (81\%), Headache (71\%), Nasal discharge (36\%) and Sneezing (29\%). Less common symptoms include Facial congestion (24\%), Posterior nasal discharge (18\%), Disturbance of smell (14\%), Aural symptoms (11\%) and Anosmia and Halitosis (1\%).

\begin{tabular}{|c|c|c|c|}
\hline Sl. No. & Symptom & No. of Cases & \% \\
\hline 1. & Nasal Obstruction & 162 & 81 \\
\hline 2. & Headache & 142 & 71 \\
3. & Nasal Discharge & 72 & 36 \\
\hline 4. & Sneezing & 58 & 29 \\
\hline 5. & Facial Congestion & 48 & 24 \\
\hline 6. & Post Nasal Discharge & 36 & 18 \\
\hline 7. & Disturbance of smell & 28 & 14 \\
\hline 8. & Aural Symptoms & 22 & 11 \\
\hline 9. & Halitosis & 12 & 6 \\
\hline 10. & Cough & 12 & 6 \\
\hline
\end{tabular}

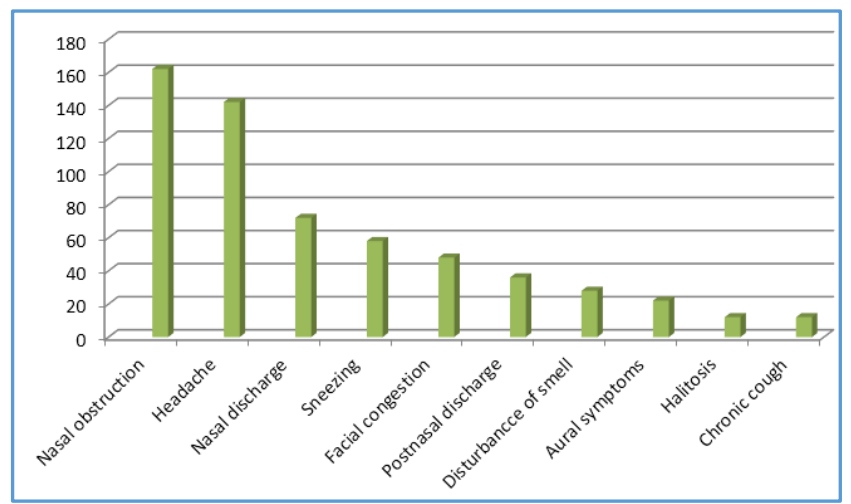

Incidence of Mucosal Abnormalities

In the present study, maxillary sinus was predominantly involved (86\%) followed by Ethmoidal sinus (72\%), Sphenoid sinus (38\%) and Frontal (34\%).

\begin{tabular}{|c|c|c|c|c|c|}
\hline Involved Sinus & Bilateral & Only Right & Only Left & Total & \% \\
\hline Maxillary & 112 & 38 & 22 & 172 & 86 \\
\hline Ethmoidal & 99 & 27 & 18 & 144 & 72 \\
\hline Frontal & 27 & 21 & 20 & 68 & 34 \\
\hline Sphenoid & 37 & 22 & 17 & 76 & 38 \\
\hline
\end{tabular}




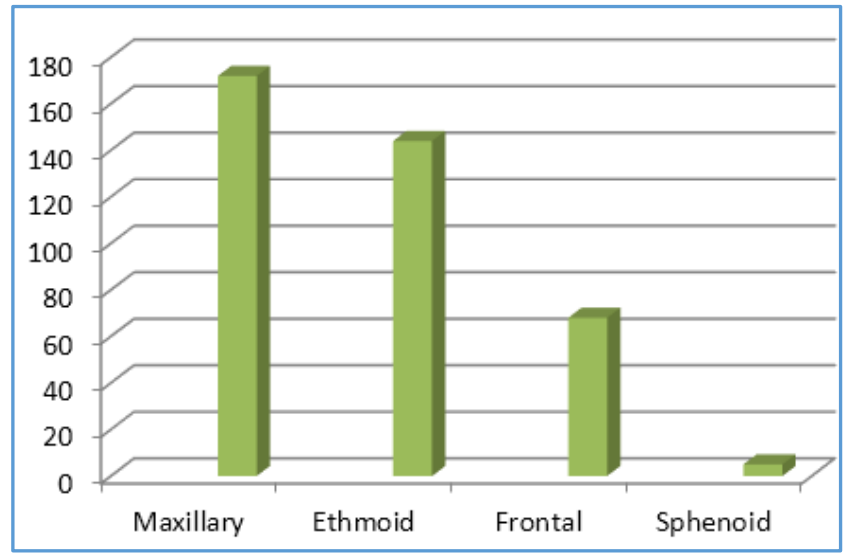

\section{Incidence of Anatomical Variations}

\begin{tabular}{|c|c|c|c|r|r|c|}
\hline $\begin{array}{c}\text { Sl. } \\
\text { No. }\end{array}$ & $\begin{array}{c}\text { Anatomical } \\
\text { Variation }\end{array}$ & Bilateral & $\begin{array}{c}\text { Only } \\
\text { Right }\end{array}$ & $\begin{array}{c}\text { Only } \\
\text { Left }\end{array}$ & Total & $\begin{array}{c}\text { Incidence } \\
\text { (\%) }\end{array}$ \\
\hline 1. & Concha Bullosa & & & & 86 & 43 \\
\hline & Lamellar & 16 & 17 & 05 & 38 & \\
\hline & Bulbous & 23 & 19 & 06 & 48 & \\
\hline 2. & $\begin{array}{c}\text { Deviated Nasal } \\
\text { Septum }\end{array}$ & - & 39 & 31 & 70 & 35 \\
\hline 3. & Agger Nasi & 58 & 14 & 10 & 82 & 41 \\
\hline 4. & Haller Cell & 11 & 07 & 05 & 22 & 11 \\
\hline 5. & $\begin{array}{c}\text { Paradoxical } \\
\text { Middle }\end{array}$ & 06 & 09 & 07 & 22 & 11 \\
\hline 6. & Large Bulla & 10 & 04 & 02 & 16 & 08 \\
\hline 7. & Onodi Cell & 06 & 05 & 01 & 12 & 06 \\
\hline 8. & $\begin{array}{c}\text { Pneumatised } \\
\text { Uncinate }\end{array}$ & 02 & 02 & 02 & 06 & 03 \\
\hline
\end{tabular}

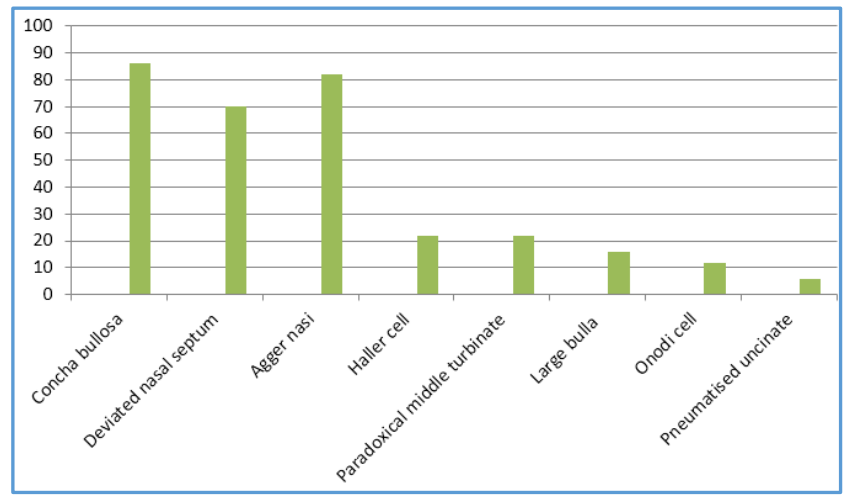

In the present study of 200 cases Concha bullosa was seen in 86 cases, of which 38 were lamellar and 48 were bulbous. Deviated nasal septum was seen in 70 cases, of which 39 showed right deviation and 31 showed left deviation. Agger nasi cells were seen in 82 cases, of which 58 were bilateral, 14 were to the left and 10 were to the right. The Haller cells were seen in 22 cases of which 11 were bilateral, 7 were to the right and 5 were to the left. The paradoxical middle turbinate was seen in a total of 22 cases of which 6 were bilateral, 9 were to the right and 7 were to the left. The large bulla were noted in a total of 16 cases of which 10 were bilateral, 4 were to the right and 2 were to the left. Onodi cells were seen in a total of 12 cases of which 6 were bilateral, 5 were towards the right and only 1 was to the left. A pneumatised uncinate was seen in a total of 6 cases of which
2 each were seen to have a bilateral distribution, right unilateral and left unilateral distribution respectively.

\section{DISCUSSION}

Anatomical variations in the sinonasal region in cases of clinical sinusitis are very common. Messerklinger ${ }^{1}$ (1978) found anatomical variations like nasal septum deviation, spur, concha bullosa, Agger nasi cells, paradoxical middle turbinate, abnormal uncinate process and enlarged bulla are responsible for decreased sinus ventilation and pathogenesis of sinus disease. Mafee $\mathrm{MF}^{2}$ et al described the use of coronal plane CT scans PNS to evaluate the topographic relations of anatomical structures at lateral wall of nose in cases of sinus disease.

\section{Concha Bullosa}

Concha bullosa is a result of pneumatisation of the osseous plate of middle turbinate. The concha pneumatisation may occur at several degrees, from that affecting only the bulbous portion (distal) or lamellar portion (proximal) or called the true variant where there is pneumatisation of both portions. ${ }^{3}$ Zinreich et al report that concha bullosa are best diagnosed radiographically and easily identified with CT. ${ }^{4}$ Bolger et al reported this pneumatisation in $53 \%$ of the sinus patients, as an extension of the anterior air cells (55\%) or posterior (45\%) ethmoidal air cells.

In the present study of 200 cases Concha bullosa was seen in 86 cases, of which 38 were lamellar and 48 were bulbous.

\section{Deviated Nasal Septum}

Deviation of the nasal septum can be defined as any midline deviation.5,6 Septal deviations may be cartilaginous, cartilaginous-bony type or a combination of both. Since septal deviation causes lateral compression of the middle turbinate and uncinated process pushing them into the infundibulum and thus causes obstruction of osteomeatal complex. Deviation of the nasal septum was found in $35 \%$ of cases in the present study.

\section{Agger Nasi Cells}

Agger nasi cells are the most anterior ethmoid cells and extend anteriorly into the lacrimal bone. They are located in the anterior floor of the frontal sinus, on the drainage pathway of the frontal sinus and therefore are possibly involved in recurrent or chronic frontal sinusitis. Schaefer et $\mathrm{al}^{7}$ reported an incidence of $10 \%$, while Van Alyea ${ }^{8}$ had observed an incidence of $89 \%$ in their series of anatomic dissections. In the present study, $41 \%$ of the patients showed Agger nasi indication.

\section{Haller Cell}

Haller's cell is the pneumatisation of the anterior ethmoid cells into the roof of the maxillary sinus extending into the floor of the orbit. Zinreich reported it in $10 \%$ of cases. ${ }^{9}$ Bolger reported it in $45.1 \%$ of cases. Lloyd reported it in $15 \%$ of cases. $^{10}$ Earwaker reported it in $20 \%$ of cases. Bolger described the possible reasons for this discrepancy as a consequence of difference in interpretation of Haller cell, sample study or in the technique of CT scanning. Bolger also suggested that a narrow window setting often fails to delineate Haller cell. In the present study, Haller cells were 
seen in 22 cases of which 11 were bilateral, 7 were to the right and 5 were to the left.

\section{Paradoxical Middle Turbinate}

Paradoxical middle turbinate occurs if the convexity of the middle turbinate is directed towards the medial wall of the maxillary sinus. In the present study the paradoxical middle turbinate was seen in a total of 22 cases, of which 6 were bilateral, 9 were to the right and 7 were to the left.

\section{Large Bulla}

An enlarged ethmoidal bulla may obstruct the infundibulum or the middle meatus. The exact prevalence of enlarged ethmoidal bulla is not known. ${ }^{11}$ Its size is an important factor when associated with opacification of anterior ethmoidal cells at CT in patients diagnosed with sinusopathy. ${ }^{12}$ In measurements at CT in adults, the average area of each ethmoidal cell is $0.73 \pm 0.42 \mathrm{~cm}$, the larger ones, situated in the posterior portion of ethmoid, measure $1.46 \pm 0.64 \mathrm{~cm} . .^{13}$

Since the ethmoidal bulla is the largest anterior cell, ${ }^{14}$ it is implicit that its average area should not exceed $2.1 \mathrm{~cm}$. In the present study the large bulla were noted in a total of 16 cases of which 10 were bilateral, 4 were to the right and 2 were to the left.

\section{Onodi Cell}

Also known as sphenoethmoidal cells, Onodi cells were first described by the Hungarian laryngologist Adolf Onodi in 1904.15 Onodi cells are ethmoid cells that have migrated to the anterior region of the sphenoid sinus with anterosuperior location and intimately related to the optic nerve causing optic neuropathy in case of certain conditions that affect such cells. Onodi cell is the most posterior ethmoid air cell that extends laterally. This extension is near the carotid canal and close to the optic nerve, which emphasises the clinical importance of considering this anatomic variation prior to any attempt for invasive intervention. The surgeon must pay close attention to the occasional Onodi cell in preoperative evaluation to avoid potential complications of endoscopic sinus surgery. In the present study Onodi cells were seen in a total of 12 cases of which 6 were bilateral, 5 were towards the right and only 1 was to the left.

\section{Pneumatised Uncinate}

The pneumatisation of the uncinated process is very rare. In the present study, a pneumatised uncinate was seen in a total of 6 cases of which 2 each were seen to have a bilateral distribution, right unilateral and left unilateral distribution respectively.

\section{CONCLUSION}

The present study was conducted to analyse the relationship of anatomical variations and rhinosinusitis and observed variations like Concha Bullosa, Deviated Nasal Septum and Agger Nasi which were the major conditions that led to sinusitis. Haller Cell, Paradoxical Middle Turbinate and Large Bulla were seen in some cases.

These variations, by obstructing the drainage pathway of the paranasal sinuses, impair the drainage of secretions from the sinuses, which subsequently may get infected, which impairs ciliary activity and aggravates stasis of secretions.
Detection of these variations and their correction (those possible) at surgery is necessary to prevent recurrence of the disease. We conclude that these Anatomical Variations can play an important role in the pathogenesis of sinusitis.

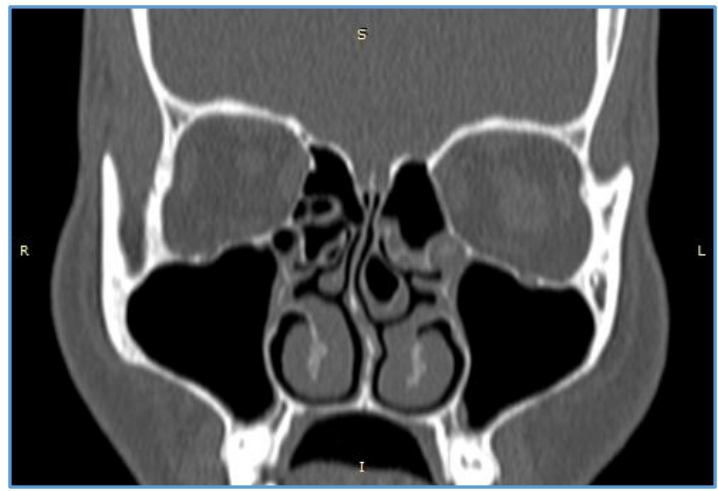

Figure 1. Bulla type of Concha

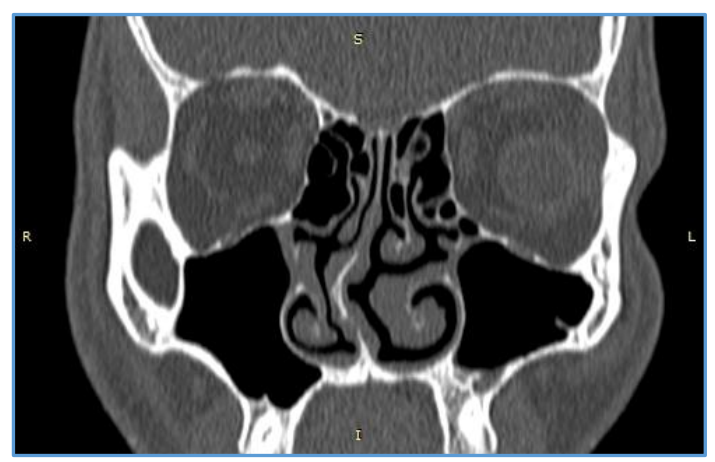

Figure 2. DNS huge Bulla_Paradaxical_Middle_Turbinate_ Lamellar_Concha

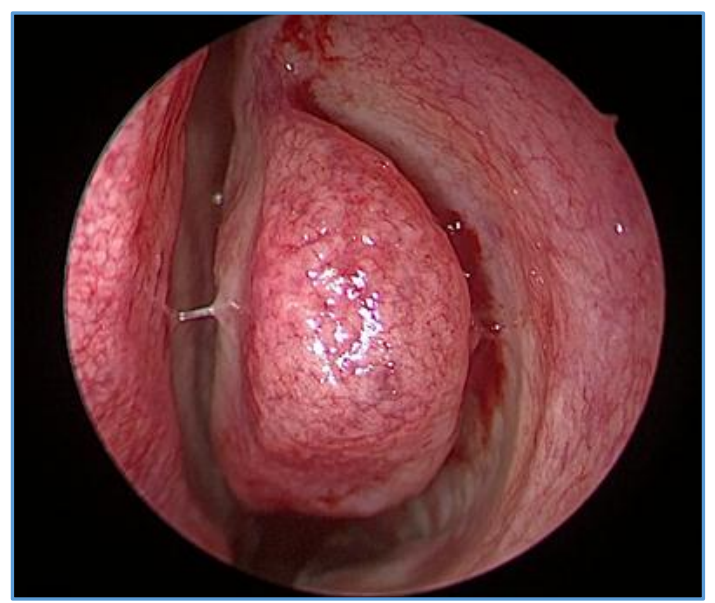

Figure 3. Concha Bullosa Photo

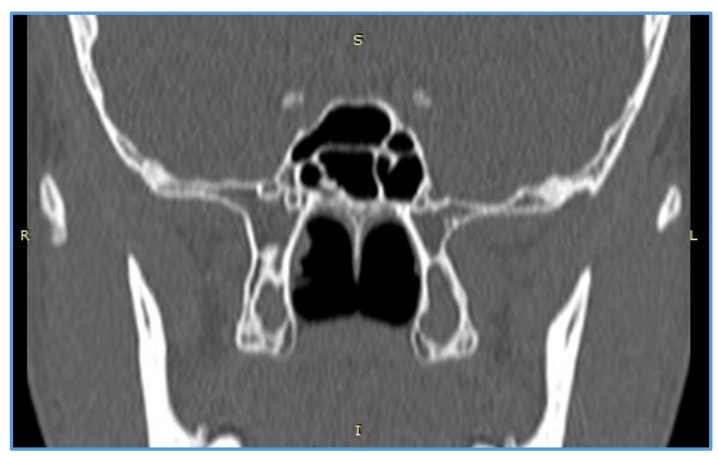

Figure 4. Onodi Cell 


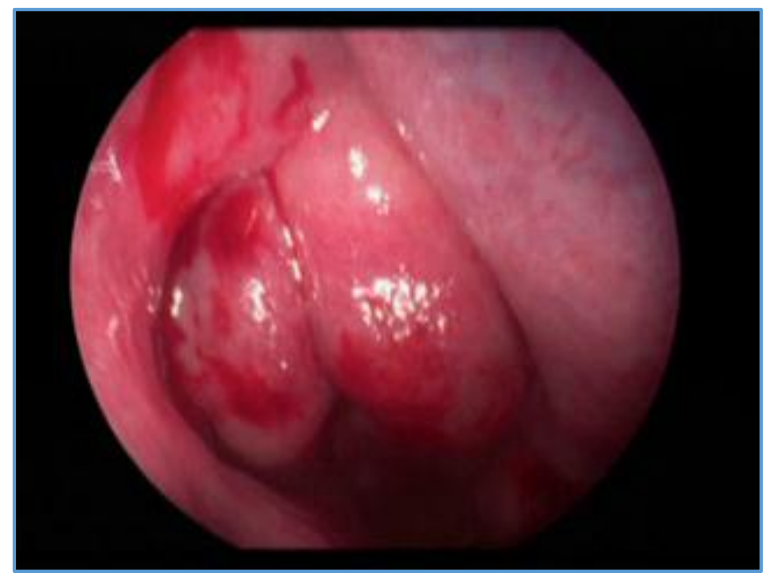

Figure 5. Double Middle Turbinate Appearance

\section{REFERENCES}

[1] Messerklinger W. Endoscopy of the nose. Baltimore, MD: Urban \& Schwarzenberg 1978.

[2] Mafee MF. Endoscopic sinus surgery: role of the radiologist. AJNR Am J Neuro Radiol 1991;12(5):85560.

[3] Bolger WE, Butzin CA, Parsons DS. Paranasal sinus bony anatomic variations and mucosal abnormalities: CT analysis for endoscopic sinus surgery. Laryngoscope 1991;101(1 Pt 1):56-64.

[4] Zinreich SJ, Mattox DE, Kennedy DW, et al. Concha bullosa: CT evaluation. Journal of Computer Assisted Tomography 1988;12(5):778-84.

[5] Earwaker J. Anatomic variants in sinonasal CT. Radiographics 1993;13(2):381-415.
[6] Kayalioglu G, Oyar O, Govsa F. Nasal cavity and paranasal sinus bony variations: a computed tomographic study. Rhinology 2000;38(3):108-13.

[7] Schaefer SD, Manning S, Close LG. Endoscopic paranasal sinus surgery: indications and considerations. Laryngoscope 1989;99(1):1-5.

[8] Van Alyea OE. Ethmoid labyrinth: anatomic study, with consideration of the clinical significance of its structural characteristics. Arch Otolaryngol Head Neck Surg 1939;29(6):881-902.

[9] Zinreich SJ, Kennedy DW, Rosenbaum AE, et al. Paranasal sinuses: CT imaging requirements for endoscopic surgery. Radiology 1987;163(3):769-75.

[10] Lloyd GA. CT of the paranasal sinuses: study of a control series in relation to endoscopic sinus surgery. J Laryngol Otol 1990;104(6):477-81.

[11] Laine FJ, Smoker WR. The osteomeatal unit and endoscopic surgery: anatomy, variations and imaging findings in inflammatory diseases. AJR Am J Roentgenol 1992;159(4):849-57.

[12] Liu X, Han D, Zhou B. Relationship between anatomic variations of nasal sinus and chronic sinusitis. Zhonghua Er Bi Yan Hou Ke Za Zhi 1998;33(3):149-52.

[13] Saheki T. The investigation of the structures in the ethmoidal air cells on CT. Nippon Jibiinkoka Gakkai Kaiho 1989;92(6):827-36.

[14] Dos Santos RM. Desenvolvimento dos seios paranasais: estudo por ressonância magnética do crânio. (Tese de Mestrado). São Paulo: Universidade Federal de São Paulo 2002.

[15] Onodi A. Die Sehstoerungen und Erblidung nasalen Ursprunges, bedingt durch Erkrankungen der hinteren Nebenhoehlen. Zeitschrift fur Augenheilkunde 1904;12:23-46. 